\title{
Między kamuflażem a stereotypem. Postać Żydówki w dramacie Gabrieli Zapolskiej Nerwowa awantura
}

\author{
BETWEEN CAMOUFLAGE AND STEREOTYPE: THE PORTRAYAL \\ OF A JEWISH WOMAN IN GABRIELA ZAPOLSKA'S DRAMA \\ NERWOWA AWANTURA [THE NERVOUS ROW]
}

\begin{abstract}
The article is an attempt to analyze Gabriela Zapolska's drama entitled Nerwowa awantura [The Nervous Row], first published in 2012. The aim of the study is to answer the question whether Zapolska, while adding Peruwianka to other figures of Jewish women in her literary output, succumbed to popular opinions and provided her with stereotypical features. Or, on the contrary, perhaps she created her protagonist in an innovative, unprecedented way? The author is trying to answer the question whether the ideas of emancipation and feminist movements, so close to the writer, an attempt to fight the existing patriarchal order and Victorian bourgeois customs, also resonate in Nerwowa awantura. The analysis shows that there are no figures of Jewish women in Zapolska's oeuvre who are clearly burdened with stereotypical traits or are completely free of them. However, none of the Jewish female characters created by the playwright is so independent, liberated and able to achieve her goals as Peruwianka, and as a result she can be perceived as a new figure on the literary and theatrical map.
\end{abstract}

Keywords: Jewish woman, prostitute, drama, Zapolska, stereotype, Young Poland.

Słowa kluczowe: Żydówka, prostytutka, dramat, Zapolska, stereotyp, Młoda Polska.

W wydanym w 2012 r. w Katowicach zbiorze niedrukowanych do tej pory dramatów Gabrieli Zapolskiej znalazła się Nerwowa awantura. Ta składająca się z trzech aktów sztuka, wystawiona po raz pierwszy w marcu 1912 r. w Teatrze Miejskim w Krakowie, była pisana na raty. Pomysł na 
sensacyjny w wydźwięku dramat miał się zrodzić już w 1910 r. w czasie zagranicznego pobytu Zapolskiej. Co do genezy jego powstania - Antoni Waśkowski tak ją opisał w artykule z 4 lutego 1911 r. zamieszczonym w „Kurierze Warszawskim”: „Akcja rozgrywa się wśród polskiego towarzystwa zgromadzonego w Nicei i Monte Carlo. Sztuka jest oparta na bezpośrednich obserwacjach, które autorka zebrała podczas ostatniego pobytu na Riwierze"1. Zapolska, która Nerwowa awanturę pisała dla Teatru Rozmaitości, planowała ukończyć ją szybko; fragment dramatu stanowiący zapowiedź przedstawienia (akt I, scena 9) został opublikowany w „Gazecie Wieczornej” 20 maja $1911 \mathrm{r}$.

Pisarka włożyła wiele wysiłku, by dramatowi, którego bezlitosnej krytyki się obawiała, zjednać przychylność przynajmniej części recenzentów. W liście do Ludwika Szczepańskiego, redaktora krakowskich „Nowin dla Wszystkich”, prosiła o podtrzymanie Nerwowej awantury i łaskawą ocenę. Podobny, pełen kokieterii list wystosowała do redakcji dziennika „Naprzód”. O łaskawe przyjęcie prosiła też Wilhelma Feldmana i jego „Krytykę”. Jednak mimo wielu starań autorki, osobistego współreżyserowania Nerwowej awantury we Lwowie, zabiegów prawie dyplomatycznych i kokietowania recenzentów sztuka nie zebrała dobrych opinii. W czasopismach przychylniej nastawionych do autorki Moralności pani Dulskiej zwracano uwagę przede wszystkim na jej niezwykłą łatwość w żonglowaniu efektami scenicznymi i talent pisarki, jednak i tam sztuka spotykała się z krytyczną oceną. Recenzenci podkreślali przede wszystkim marionetkowość głównych bohaterów, chaotyczność w operowaniu efektami scenicznymi, nieprawdziwy obraz Riwiery, która w sztuce Zapolskiej jest ponura, przygnębiająca i pozbawiona jakiegokolwiek uroku. Pojawiły się także zarzuty, że jedna z bohaterek, Peruwianka, która okazała się galicyjską Żydówką z Drohobycza, jest postacią całkowicie nieprawdopodobną, a tym samym sztuczną; jej wprowadzenie do dramatu uznano za zabieg naiwny, co sprawiło, że realizm świata przedstawionego został poważnie nadwerężony i zaburzony. Recenzenci pytali: ileż Peruwianek zabawiało się w kasynach francuskiej Riwiery? Pomysł wprowadzenia egzotycznej kokoty docenił Boy-Żeleński, który przyznał, że rzeczywiście jest on bardzo wymyślony, ale daje niezwykły efekt, zwłaszcza gdy Żydówka w przebraniu

${ }^{1}$ Antoni Waśkowski, „Kurier Warszawski” (4 lutego 1911). Cyt. za: Jadwiga Czachowska, Gabriela Zapolska. Monografia bio-bibliograficzna, Kraków 1966, s. 461. 
Peruwianki „odzywa się do urodziwego bohatera najczystszym kaźmierskim akcentem: »Oddaj mi pan moje branzoletkie «"2.

Zapolska krytykę odpiera, nie szczędząc recenzentom złośliwości i wyolbrzymiając entuzjazm, z jakim premiera została przyjęta w Krakowie. W korespondencji do Stanisława Janowskiego broni pomysłu wprowadzenia na scenę egzotycznej kurtyzany: „Co do efektu z Peruwianką, dlatego wyszedł mocno i jaskrawo, bo grany był w tym tonie. Peruwianka jest kokotą europejską - międzynarodową - w dużym stylu - piękną i prawie realistycznie demoniczną - a nie śledziarką lwowską"3.

\section{Żydówka w przebraniu}

Jak zauważa w posłowiu Jan Jakóbczyk, redaktor wydania Niedrukowanych dramatów Gabrieli Zapolskiej ${ }^{4}$, pisarka, powołując do życia bohaterów sztuki i splatając przez krótką chwilę na francuskim wybrzeżu ich zagmatwane losy, niejako wyprzedziła swoją epokę, zwracając uwagę na ważne fakty mające do dzisiaj istotny wydźwięk, czego ówczesna krytyka nie umiała dostrzec. Teza, że przyjęta przez recenzentów aksjologia sprzed ponad stu laty skutkowała zbyt jednoznacznymi, a tym samym uproszczonymi ocenami, co w efekcie prowadziło do pominięcia niezwykle istotnych motywów, wydaje mi się słuszna. Z pewnością z taką szablonową i tym samym niesprawiedliwą oceną spotkała się Peruwianka, która jest chyba najbardziej barwną, oryginalną i budzącą kontrowersje postacią Nerwowej awantury i która jednocześnie najmocniej intryguje, pociąga i skłania do uważnej, bliskiej lektury utworu.

Egzotycznie wyglądająca i niezwykle efektowna kobieta jest jedną z osób bawiących w hotelu Monte Carlo, do którego przyjeżdża utracjusz, hochsztapler i oszust Stanisław Frankowski. Towarzyszy mu Maria, kochanka i była nauczycielka jego dzieci, z którą potajemnie uciekł z należącego do jego żony majątku na rosyjskim Podolu. Frankowski nie ma pieniędzy ani perspektyw na ich zdobycie, nękają go wierzyciele, obawia się aresztowania z powodu niezapłaconych rachunków. Jedynej szansy

2 Tadeusz Boy-Żeleński, [recenzja], Nerwowa awantura, „Czas” (1921), nr 130, s. 2; przedruk w: Tadeusz Boy-Żeleński, Pisma, t. 20, red. Henryk Markiewicz, oprac. i przedmowa Jan Kott, Warszawa 1963, s. 51-55.

${ }^{3}$ Gabriela Zapolska, Listy, t. 2, oprac. Stefania Linowska, Warszawa 1970, s. 550.

${ }^{4}$ Niedrukowane dramaty Gabrieli Zapolskiej, t. 1: „Nerwowa awantura” oraz „Pariasy”, red. Jan Jakóbczyk, Katowice 2012, [e-book, format: mobi]. 
na poprawienie sytuacji finansowej upatruje w ruletce. W tym samym hotelu przebywa w towarzystwie młodej, schorowanej damy - Osmólskiej znajomy rodziny Frankowskiego, niejaki Romański. Dowiedziawszy się, że Frankowskiemu towarzyszy kochanka, a nie żona, którą zna i lubi, postanowił przywrócić go na łono rodziny, proponując Marii pieniądze w zamian za jej wyjazd. W tym celu wysyła do żony Frankowskiego telegram, w którym próbuje ustalić warunki powrotu wiarołomnego męża do domu. Maria godzi się wyjechać, zwłaszcza że między nią a Stachem panuje ciągłe napięcie, a brak jakichkolwiek środków do życia jest przyczyną nieustannych awantur między kochankami. Frankowski, dowiedziawszy się, że kobieta w tajemniczy sposób zdobyła pieniądze, przekonuje ją, by została, zapewnia o swojej miłości i proponuje, iż schowa banknoty w bezpiecznym miejscu. Tymczasem przegrywa ostatecznie i tę niewielką kwotę w kasynie. Znajduje za to pocieszenie u boku tajemniczej pięknej kokoty, Peruwianki, która do Monte Carlo przybyła w towarzystwie notariusza Kozaneckiego. Tajemnicza awanturnica flirtuje z Frankowskim, nęcąc go jednocześnie przymiotami swojej urody i majątkiem. Celowo upuszcza bransoletkę, którą utracjusz podnosi i chowa do kieszeni, tym samym stając się w pewnym sensie jej zakładnikiem. Peruwianka wyznaje mu, że jest Żydówką z Drohobycza, która dzięki zmianie tożsamości mogła wyrwać się z żydowskiego miasteczka i trafić na salony Europy. Proponuje Frankowskiemu, by ten porzucił Marię i pomysł powrotu na Podole, a następnie wyjechał z nią do Paryża, gdzie planuje otworzyć ekskluzywny dom gry. By jej pomysł się ziścił w zdominowanym przez mężczyzn świecie, potrzebny jest jej jeden z nich, który będzie reprezentował ją w interesach. Propozycja - co kobieta podkreśla - ma charakter wyłącznie handlowy. Jednocześnie ostrzega Frankowskiego, że jeśli ten nie zgodzi się przyjąć jej oferty, musi zachować milczenie co do jej pochodzenia - w przeciwnym bowiem razie rozpowie wszystkim, iż ukradł jej bransoletkę. Hochsztapler, choć początkowo zaskoczony i zdezorientowany propozycją kobiety, zdaje się upatrywać w niej swojej szansy. Historia jednak kończy się tragicznie: Maria, do której Peruwianka przychodzi z radą, by zostawiła Frankowskiego, wpada w szał i zabija kochanka strzałem z pistoletu.

\section{Mitologizacja kobiecej seksualności}

Przełom wieków XIX i XX to czas, w którym dyskusje o roli kobiety, kwestiach jej praw społecznych i politycznych, możliwościach edukacyjnych 
i zarobkowych stają się wyjątkowo żywe5. Wizerunek kobiety w sztuce i literaturze rozszczepia się na dwa skrajne obrazy: $z$ jednej strony pojawia się typ kobiety świadomej, dojrzałej intelektualnie, a z drugiej takiej, która jest ucieleśnieniem demonicznej siły i obcości jednocześnie. Ta inna kobieta poprzez swoją seksualność i zwierzęcość stanowi zagrożenie dla porządku męskiego ${ }^{6}$. Tu seksizm jest takim samym uprzedzeniem jak rasizm wobec Żydów, uniemożliwiając jakąkolwiek „asymilację” kobiet. Do postaci Peruwianki zdaje się pasować diagnoza postawiona kobietom przez mizogina Ottona Weinigera, który w wydanej w 1903 r. niezwykle popularnej w całej Europie pracy Płeć $i$ charakter tak definiował kobiecość:

Istota doskonale kobieca nie zna ani logicznego, ani moralnego imperatywu, a wyraz prawo, wyraz obowiązek, obowiązek względem siebie samego, jest spośród wszystkich najbardziej dla niej obco brzmiącym wyrazem. A przeto zupełnie uprawniony jest stąd wniosek, że nie posiada ona też osobowości ponadzmysłowej?

Wierzono, że kobieta - jako pozbawiona podmiotowości - kieruje się w życiu instynktownym popędem, co de facto sytuuje ją w świecie zwierzęcym. Jest jednostką niesamodzielną, nieautonomiczną, alogiczną i amoralną, w związku z czym umie manifestować swoją tożsamość wyłącznie poprzez ciało, a to jest równoznaczne z brakiem jakichkolwiek przymiotów duchowych (nie posiada duszy) i etycznych ${ }^{8}$. Kobieta, będąca nosicielką niszczycielskiej siły, stanowi także źródło destrukcji, która staje się męskim udziałem właśnie poprzez miłość cielesną9. Mitologizacja kobiecej seksualności urzeczywistnia się w okresie modernizmu nie tylko

${ }^{5}$ Zob. Gabriela Matuszek, Kultura contra natura? O mizoginizmie minionego fin de siècle’u, [w:] W kręgu Młodej Polski. Prace ofiarowane Marii Podrazie-Kwiatkowskiej, red. Marian Stala, Franciszek Ziejka, Kraków 2001, s. 47.

${ }^{6}$ Zob. Wojciech Gutowski, Nagie dusze i maski: o młodopolskich mitach miłości, Kraków 1992.

${ }^{7}$ Otto Weininger, Pteć $i$ charakter, thum. Ostap Ortwin, Warszawa 1994, s. 24. Zob. artykuł Katarzyny Wojnickiej Otto Weininger: mizogin i profeminista?, „Autobiografia. Literatura. Kultura. Media” (2016), nr 1, s. 39-58. Badaczka wskazuje w nim, że uważna lektura Płci i charakteru pozwala spostrzec, iż oprócz niezaprzeczalnej mizoginii charakteryzowało autora też specyficzne spojrzenie na sytuację kobiet, które to spojrzenie w wielu momentach uznać można za bardzo progresywne i spójne z postulatami myśli (pro)feministycznej.

${ }^{8}$ Zob. David D. Gilmore, Mizoginia, czyli męska choroba, tłum. Janusz Margański, Kraków 2003, s. 302. Autor wskazuje na różnorakie i wielokontekstowe źródła mizoginii, używając m.in. takich teorii, jak: freudowski lęk kastracyjny, behawiorystyczna teoria frustracji-agresji, teoria zależności psychicznej.

9 Zob. Elaine Showalter, Przedstawiajac Ofelię: kobiety, szaleństwo i zadania krytyki feministycznej, [w:] Ciało i tekst. Feminizm w literaturoznawstwie - antologia szkiców, red. Anna Nasiłowska, Warszawa 2001, s. 190. 
w sztuce i literaturze, ale także w wielu innych dziedzinach, m.in. filozofii, medycynie, antropologii. W efekcie po raz kolejny w historii szerzy się mit kobiety dynamicznej, Schopenhauerowskiego „czarnego demona”, ekspansywnego, wyzwolonego z norm obyczajowych, którego demoniczna i destrukcyjna siła zagraża męskiemu porządkowi ${ }^{10}$.

Peruwianka zdaje się doskonale realizować to wyobrażenie o kobiecie całkowicie pozbawionej zasad moralnych. Zarabia ciałem, świadcząc usługi seksualne, perfidnie i z wyrachowaniem oszukuje swoich współtowarzyszy, nie zdradzając prawdziwej tożsamości. Zdobytą niejako podstępem wiedzę - wszak nie wyjawia im, że doskonale zna język, którego używają, i wszystko rozumie, gdy ją obrażają lub się z niej naśmiewają - wykorzystuje do realizacji swoich własnych interesów. Traktuje ludzi instrumentalnie; gdy notariusz Kozanecki przestaje jej być potrzebny, nie waha się wyrzucić go z samochodu. Frankowski interesuje ją o tyle, o ile jest w stanie pomóc jej w interesach. Cechy, które w nim docenia, to bezwzględność, zdolność do kradzieży i... uroda. Mówi o nim „pan jest mój człowiek...”11. O jej demoniczności zdają się także świadczyć przymioty ciała; to - jak pisze Zapolska - „typowa francuska kokota, silnie czarna, silna brunetka, ubrana wspaniale, milcząca i nieruchoma - twarz jej ma pozór Sfinksa, czasem tylko zaczepiona - zdawkowo się uśmiecha, obwieszona wspaniałą biżuterią, nadzwyczaj wypielęgnowana, ale nie rasowa"12.

Choć Peruwianka wydaje się postacią jednoznacznie negatywną, trudno pominąć kwestie jej trudnych doświadczeń życiowych. W rozmowie z Frankowskim wyznaje: „Ja znam ludzi na wskroś, oni mnie dosyć nadeptali. A jak oni mnie deptali, to ja się na nich patrzyła - i tak jak się nauczyłam wiedzieć, co oni warci" ${ }^{\prime 3}$. Milczenie i egzotyczna maska stanowią jej oręż w walce z nieprzychylnym kobiecie światem. Przywdzianie kostiumu sfinksa pozwala jej jednocześnie zdobywać wiedzę niezbędną do przetrwania oraz poznawać prawdziwe intencje innych. Mężczyźni z towarzystwa często mówią o niej jak o przedmiocie, traktują raczej jak egzotyczne zwierzę, maskotkę niż człowieka. Dziennikarz Dalke pyta Peruwiankę: „Co? Czarna

${ }^{10}$ Zob. Maria Podraza-Kwiatkowska, Salome i Androgyne. Mizoginizm a emancypacja, [w:] taż, Symbolizm i symbolika w poezji Młodej Polski. Teoria i praktyka, Kraków 1975, s. 363. Podraza-Kwiatkowska zwraca uwagę, że modernizm to czas, w którym na nowo stają się żywe mity sytuujące kobietę po stronie natury, szatana, chaosu, nadprzyrodzonej siły, przedstawiając ją jako tę, która jak modliszka pożera samca, jest kobietą wampirem.

${ }^{11}$ Niedrukowane dramaty..., s. 108.

12 Tamże, s. 37.

13 Tamże, s. 109. 
biedo?"14. Gdy Maria zwraca mu uwagę na nietakt, Kozanecki uspokaja: „Nie szkodzi! Nie szkodzi! Ja jak się rozgniewam, to ją bardzo często nieparlamentarnie nazywam, a ona przecież nic - bo jakże... Strasznie się cieszę, że mam najczarniejszą kobietę w całym Monte Carlo"15. Dla notariusza żadne przymioty osobowości jego towarzyszki nie mają najmniejszego znaczenia. Postrzega ją tylko poprzez egzotykę jej pochodzenia i urody. Tłumaczy Dalkemu: „Peruwianka - to rzadki ptak - rara avis ${ }^{16}$ Tapada... jakie oko, jaka płeć, jaka noga - zaraz to można poznać, że to coś stamtąd pokazuje na podłogę. Żeby ją tak można do Warszawy, panie tego... ale co? Nie pojedzie..."17. Tymczasem francuska kokota, o czym wiadomo z didaskaliów, w reakcji na słowa swoich współtowarzyszy „wyrzyna pogardliwie wargi”, „patrzy [...] z pogardą"18. Jednocześnie, co podkreśla notariusz, kobieta „zachowuje się bardzo przyzwoicie. Zawsze milczy. Arystokratka" ${ }^{19}$. Peruwianka mimo to w oczach współtowarzyszy nie zasługuje na szacunek, ponieważ jest prostytutką. Gardzą nią zarówno Romański, jak i Maria, która nie jest przecież postacią kryształową (uciekła z mężem swojej chlebodawczyni). Mówi jednak o Peruwiance, odnosząc się do jej profesji, że to „istota z błota, kałuży”20. Notariusz Kozanecki jest przekonany, że jego towarzyszka pochodzi z królewskiego rodu albo co najmniej z wysoko urodzonej peruwiańskiej rodziny, co w jego oczach zdecydowanie dodaje jej (i tym samym jemu) prestiżu. Można przypuszczać, że tylko dzięki temu jest tolerowana przez polskie towarzystwo na Riwierze. Choć recenzenci zarzucali Zapolskiej, że postać Peruwianki jest całkowicie nieprawdopodobna i tym samym stanowi w dramacie element niemal fantastyczny, to z dzisiejszej perspektywy nie wydaje się ona już tak egzotyczna. $Z$ drugiej strony można też przypuszczać, że zarówno dla współczesnego czytelnika dramatu, jak i dla krytyków Nerwowej awantury w Krakowie i we Lwowie nie do końca czytelny był (i jest) szerszy kontekst związany z trudnym położeniem, w jakim znajdowały się kobiety należące do najbiedniejszych galicyjskich mas, w tym Żydówki.

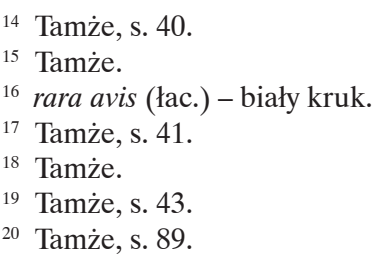




\section{Galizianerinnen}

W 1901 r. urodzona w Wiedniu, ale mieszkająca we Frankfurcie działaczka na rzecz spraw żydowskich kobiet, Bertha Pappenheim ${ }^{21}$, wygłosiła wykład na temat rzekomej „niemoralności” Żydówek. Ówcześnie powszechnie panująca opinia głosiła, że wszystkie one trudnią się prostytucją nie tylko w Galicji, ale także w Niemczech i Austrii. Określano je mianem Galizianerinnen, co kwalifikowało je do osobnej i rozpoznawalnej grupy społecznej kobiet. Pappenheim przekonywała jednak, że oddawanie się prostytucji nie wynikało z ich wrodzonego, naturalnego braku moralności, lecz przyczyn tego procederu należy upatrywać w ciemnocie, potwornej nędzy i fatalnych warunkach życia ${ }^{22}$. W 1903 r. Pappenheim na zlecenie żydowskich organizacji dobroczynnych odbyła w towarzystwie rosyjskiej ekonomistki Sary Rabinowitsch podróż po Galicji, by „się zorientować w krytycznym położeniu żydowskich mas i zdać z tego sprawozdanie"23. Efektem tych peregrynacji był opublikowany w 1904 r. we Frankfurcie raport Zur Lage der jüdischen Bevölkerung in Galizien: Reise-Eindrücke und Vorschläge zur Besserung der Verhältnisse ${ }^{24}$ [O położeniu żydowskiej ludności w Galicji. Wrażenia z podróży i propozycje w sprawie poprawy warunków bytowania], w którym Pappenheim i Rabinowitsch zwróciły uwagę m.in. na niezwykle poważną i powszechną w Galicji kwestię handlu kobietami, jak również powiązały ją z emigracją. Ucieczki z monarchii austro-węgierskiej do Ameryki miały wtedy charakter masowy. Rzesze biedaków, skuszone obietnicą lepszego i dostatniejszego życia za oceanem, wsiadały na parowce w Hamburgu, wcześniej opłaciwszy słono pośredników i bilet, na który często się składała cała rodzina. Wiele młodych kobiet, skuszonych propozycją pracy w roli opiekunki do dzieci czy służącej w zamożnych domach amerykańskich, tancerki lub kelnerki w eleganckiej kawiarni, godziło się na wyjazd, nie

${ }^{21}$ Bertha Pappenheim pochodziła z zamożnej mieszczańskiej rodziny żydowskiej i przeszła do historii nie tylko dzięki swojej działalności na rzecz emancypacji kobiet, walcząc o ich równouprawnienie w gminach żydowskich, ale także za sprawą psychoanalizy, w młodości była bowiem pacjentką psychiatryczną Josepha Breuera. Jej przypadek - jako Anny O. - został opisany w 1895 r. przez Zygmunta Freuda w jego Studiach nad histeria.

${ }_{22}$ Zob. Larry Wolff, Idea Galicji. Historia i fantazja w kulturze politycznej Habsburgów, tłum. Tomasz Bieroń, Kraków 2020, s. 462.

${ }_{23}$ Zob. Martin Pollack, Cesarz Ameryki. Wielka ucieczka z Galicji, thum. Karolina Niedenthal, Wołowiec 2012, s. 60.

${ }^{24}$ Bertha Pappenheim, Zur Lage der jüdischen Bevölkerung in Galizien: Reise-Eindrücke und Vorschläge zur Besserung der Verhältnisse, Frankfurt am Main 1904, https://www.deutschestextarchiv.de/book/view/pappenheim_galizien_1904?p=1 [dostęp: 27 sierpnia 2021]. 
zdając sobie sprawy, że celem ich podróży nie jest dobrze płatna posada, lecz dom publiczny. W studium O położeniu żydowskiej ludności w Galicji... Pappenheim pisała:

Występowanie handlu żywym towarem pozostaje w bezpośrednim związku z masowymi wyjazdami, których w Galicji nie da się powstrzymać. W kraju, który nie może wyżywić swych mieszkańców, musi dochodzić do wzmożonej emigracji. [...] Gotowości do wyjazdu sprzyja niesłychana łatwowierność, która ułatwia werbunek pozbawionym skrupułów agentom, a także całkowita niewiedza ludu. Robotnicy i chłopi wykazują na przykład nieznajomość jakichkolwiek pojęć geograficznych. Skoro nie wiedzą, czy Ameryka nie jest przypadkiem miastem, które leży niedaleko Londynu, nie zdają sobie sprawy, ile trzeba czasu, żeby dokądkolwiek dotrzeć, nie potrafią pisać ani czytać, nie oczekują więc żadnych listów i bezpośrednich wiadomości, nie mogliby zresztą skontrolować ich prawdziwości, zatem każda wyjeżdżająca, to znaczy opuszczająca swoją rodzinną miejscowość, dziewczyna wystawiona jest na różne przypadki i niegodziwości jeszcze na terenie kraju ${ }^{25}$.

Jak twierdzi Martin Pollack, niektóre kobiety najpewniej miały świadomość, że po przyjeździe do nowego kraju będą pracowały jako prostytutki, ale z powodu młodzieńczej naiwności, braku edukacji i doświadczenia życiowego ulegały iluzji beztroskiego życia i łatwych zarobków ${ }^{26}$. Tymczasem były bite, gwałcone, okradane, a ich dług wobec stręczycieli nieustannie rósł. Gdy podupadały na zdrowiu, były sprzedawane do coraz to gorszych domów publicznych, by na końcu tej drogi umrzeć w przytułku dla bezdomnych lub na ulicy. Część z tych kobiet trafiała do Ameryki Południowej, głównie do Argentyny i Brazylii, ale także do innych krajów, m.in. Urugwaju. Wspomina o tym Stanisław Posner, polski działacz socjalistyczny, senator I i II kadencji w II RP, prawnik i publicysta, który w 1903 r. opublikował raport Nad otchtania (w sprawie handlu żywym towarem), cz. 1, w którym pisze o coraz większych liczbach kobiet, głównie Żydówek, wywożonych za ocean i zupełnym braku kontroli administracyjnej w państwach Ameryki Południowej, co uniemożliwiało oszacowanie skali zjawiska:

W Ameryce Południowej istnieje cała organizacja handlowa skierowana ku przywozowi białych niewolnic z krajów Starego Świata. Funkcjonuje tam cały szereg „domów handlowych”, utrzymujących liczną zgraję agentów-specjalistów, wysyłanych do różnych krajów europejskich w celu werbunku odpowiednich emigrantek. Agenci ci występują najczęściej w charakterze uwodzicieli. Niekiedy ofiary zupełnie słabo orientujące się w sytuacji uprowadzają, obiecując złotodajne „miejsca”

${ }^{25}$ Bertha Pappenheim, O położeniu żydowskiej ludności w Galicji. Wrażenia z podróży i propozycje w sprawie poprawy warunków bytowania, za: Pollack, Cesarz Ameryki..., s. 60-61.

26 Tamże, s. 62. 
w charakterze bon, służących i gospodyń; wobec ofiar bardziej ostrożnych nakładają maskę konkurentów, żenią się z nimi pod fikcyjnymi nazwiskami, a gdy okręt przybije do brzegu wolnej ziemi amerykańskiej, wprost odwożą je do domów rozpusty; z góry zakontraktowana i sprzedana za umówioną cenę niewolnica taka, nieznająca języka ani zwyczajów, przede wszystkim ulega zamknięciu, odosobnieniu od świata zewnętrznego. Kiedy już wreszcie straci wszelką nadzieję powrotu, wypłacze wszystkie łzy, wyzbędzie się resztek człowieczeństwa - wtedy czcigodny opiekun, poważny patriarcha domu, wyprowadza ją na arenę. Towar pochodzi z Anglii, Niemiec, Francji, Belgii i Austrii (Galicji) w mniejszej części, w największej zaś części z południowych guberni Cesarstwa Rosyjskiego i z Królestwa Polskiego. Drogi handlowe prowadzą na Batumi, Odessę, Libawę, Hamburg i Bremę, wreszcie na Genuę i inne porty Morza Śródziemnego. W Buenos Aires i Rio de Janeiro więcej niż połowa prostytutek pod względem poddaństwa należała do państwa rosyjskiego. W mniejszym stopniu drogi zbytu prowadzą do Konstantynopola i Egiptu, wreszcie zorganizowana wymiana wzajemna prostytutek istnieje pomiędzy Francją i Anglią oraz Niemcami, Szwajcarią, Belgią i Rosją ${ }^{27}$.

Dokładna liczba kobiet wywiezionych na przełomie wieku XIX i XX z Galicji do Ameryki Południowej nie jest znana, ale szacunki mówią o ok. 10 tys. dziewcząt wywożonych rocznie. Jak twierdził polski ekonomista Leopold $\mathrm{Caro}^{28}$, specjalista ds. emigracji z Austrii, wywożenie i sprzedawanie do domów publicznych w Ameryce kobiet pochodzących z Galicji w żadnym innym kraju nie było tak łatwe i tak całkowicie bezkarne.

\section{Tapada i oręż z ciała}

Zapolska wielokrotnie w swojej twórczości dotykała sytuacji Żydówek. Jak zauważyła Danuta Knysz-Tomaszewska: „Trudna walka o skąpe zarobki autorskie i o przetrwanie w świecie teatru i literatury uczyniły ją szczególnie wrażliwą na nędzę ludzką, przemoc psychiczną i obojętność społeczeństwa na nieszczęścia kobiet samotnych, szczególnie tych z gminu"29. Zapolska zapewne doskonale zdawała sobie sprawę z sytuacji najbiedniejszych żydowskich mas, z powszechności prostytucji wśród biedoty żydowskiej i szansy, jakiej upatrywała w emigracji. W tym kontekście

${ }^{27}$ Stanisław Posner, Nad otchłania ( $w$ sprawie handlu żywym towarem), cz. 1, Warszawa 1903, s. 43, https://bc.radom.pl/dlibra/show-content/publication/edition/25331 ?id=25331 [dostęp: 27 sierpnia 2021].

${ }_{28}$ Zob. Pollack, Cesarz Ameryki..., s. 62.

29 Danuta Knysz-Tomaszewska, Gabriela Zapolska, pisarka zbuntowana (1857-1921). Biografia niepokorna, [w:] Gabriela Zapolska. Zbuntowany talent, red. Monika Chudzikowska, Warszawa 2011, s. 20-21. 
Żydówka-prostytutka nawet w kamuflażu peruwiańskiej księżniczki nie wydaje się już tak nieprawdopodobna.

Uważny czytelnik twórczości Zapolskiej wie, że pisarka nie pierwszy raz korzysta z efektu maski, dzięki której jej bohaterka-Żydówka może ukryć swoją prawdziwą tożsamość. Główna postać kobieca ze szkicu powieściowego Antysemitnik ${ }^{30}$ przybiera włosko brzmiący pseudonim artystyczny Irma Pasmantieri, który nie tylko nie zdradza jej pochodzenia, ale pozwala też ukrywać żydowskość. O tym, że Irma jest Żydówką, czytelnik dowiaduje się nie od razu i nie wprost. Podobnie jest w przypadku Peruwianki, która wyjawia prawdę o swoim pochodzeniu właściwie jedynie Frankowskiemu, bo to z nim chce robić interesy. Żydówka pyta retorycznie: „Czemu się pan dziwi? Tu się nie ma czemu dziwić. Gdybym ja nie podała się za Peruwiankę, to nikt by na mnie patrzył. A tak ja mam powodzenie - i tu, i w Paryżu"31.

Notariusz wielokrotnie nazywa Peruwiankę Tapadą. Nie do końca wiadomo, czy to jej nazwisko, czy przezwisko nadane kobiecie przez Kozaneckiego. Słowo tapada oznacza po hiszpańsku 'zakryta'. To także nazwa stroju będącego pozostałością obecności Maurów w Hiszpanii. Składają się nań długa spódnica i skrywająca twarz chusta upinana w ten sposób, że odkryty pozostaje zaledwie mały trójkąt z widocznym jednym okiem. Mianem tapadas limeñas (hiszp.) określano kreolskie kobiety, które w okresie Wicekrólestwa Peru i początkowych lat Republiki mieszkały w peruwiańskiej stolicy Limie i które w nietypowy sposób zakrywały włosy i twarz jedwabną peleryną (manto), zostawiając odsłonięte tylko jedno oko. Nosiły również długie spódnice (saya), które - wiązane na wysokości kolan - miały uwypuklić ich kobiece kształty, podkreślając linię bioder. Zmysłowy i tajemniczy charakter stroju, stanowiącego rodzaj gry w zakrywanie i ujawnianie, pozwalał kobietom na znacznie więcej niż było to dostępne w ramach patriarchalnej poprawności. Dzięki strojowi kobiety mogły ukrywać nie tylko swój wiek, lecz także kolor skóry, oczu, włosów, stan cywilny, co czyniło je postaciami całkowicie anonimowymi przede wszystkim wobec mężczyzn. Próby ograniczenia ubioru zakrywającego całe ciało, wprowadzane zakazy, wynikające głównie z obawy przed pojawiającymi się po raz pierwszy przypadkami transwestytyzmu, spełzły na niczym - mieszkanki Limy przez trzysta lat nosiły tajemnicze stroje; manto i saya pozwalały kobietom wyzwolić się spod męskiej kurateli, a tym

\footnotetext{
${ }^{30}$ Gabriela Zapolska, Antysemitnik, Kraków 1921.

${ }^{31}$ Niedrukowane dramaty..., s. 107.
} 
samym zyskać poczucie wolności ${ }^{32}$. Podobnie u Zapolskiej - przebranie pozwala Peruwiance nie tylko zdobyć prestiż, ale przede wszystkim uwolnić się z dotychczasowych ograniczeń, choć wiąże się to z wyrzeczeniem tożsamości. To sposób nie tylko na wyjście z kasty, ale także na sięgnięcie wyżej, ponad to, co oferowała asymilacja, czyli życie na pograniczu między dwoma światami. Decydując się na wyjście z diaspory, Żydówki traciły grunt pod nogami, będąc wykorzenionymi ze swojego środowiska. Na dodatek niezwykle rzadko stawały się pełnoprawnymi członkami społeczeństwa, do którego aspirowały. Oprócz ograniczeń związanych z pochodzeniem musiały pokonać również te dotyczące płci. Dzięki maskom, kamuflażowi wychodzą z metaforycznej grupy pryzmatycznej ${ }^{33}$, w której są negatywnie oceniane niezależnie od tego, co robią i kto je ocenia. Peruwianka, oferując Frankowskiemu pracę w tworzonym przez siebie luksusowym domu gry w Paryżu, przekonuje go, że będzie mu tam nieporównanie lepiej niż w Galicji, skąd pochodzi: „Pana czeka jedwabne życie. Pan będzie swobodny jak ptak w tym Paryżu. Co pan będzie jechał gnić w tej Galicji? Ja kobieta, Żydówka, a jakbym się udusiła, jakbym miała do Drohobycza z powrotem wrócić" 34 .

Elementem kamuflażu Peruwianki staje się paradoksalnie także jej ciało. Jest to o tyle zaskakujące, że odmienność żydowskiej fizjonomii należała do najważniejszych elementów antysemickich wyobrażeń o Ostjuden oraz niezasymilowanych Żydach w Polsce. Idea specyficznego żydowskiego wyglądu zyskała na znaczeniu podczas przejścia od ukształtowanego w chrześcijaństwie antyjudaizmu do nowoczesnego antysemityzmu rasistowskiego. Różnic między Żydami i nie-Żydami, dotychczas określanych według kryteriów religijnych, odtąd upatrywano głównie w ciele i uważano je za niezmienne. W XVIII w., wraz z narodzinami antropologii, nasiliły się tendencje do cielesnego odgraniczenia społeczności żydowskiej. Przełom wieku to czas, gdy cielesność staje się jedną z istotniejszych kategorii nie tylko filozoficznych, ale właśnie przede wszystkim antropologicznych. Dochodzi do niespotykanego dotąd rozwoju nauk medycznych, gdzie badanie żydowskiego ciała jako tego, które jest odmienne,

${ }^{32}$ Zob. Paulina Nowakowska, Tapadas limeñas, patrząe na świat jednym okiem, tajemnicze kobiety Wicekrólestwa Peru, „Palimpsest” (marzec 2012), nr 2, https://docplayer. pl/2880426-Tapadas-limenas-patrzace-na-swiat-jednym-okiem-tajemnicze-kobiety-wicekrolestwa-peru.html [dostęp: 27 sierpnia 2021].

33 Zygmunt Bauman, Nowoczesność i Zagłada, Kraków 2009, s. 102.

${ }^{34}$ Niedrukowane dramaty..., s. 110. 
słabsze, różne od ciała chrześcijanina, zajmowało poczesne miejsce ${ }^{35}$. Przedmiotem naukowych dywagacji i medycznych analiz stały się m.in. specyficzny żydowski chód, nos i oczy, język, ale także słaba konstrukcja psychiczna. Charakterystyczne cechy żydowskiego ciała były niezmiennym znakiem rozpoznawczym, który od razu pozwalał identyfikować członków tej odmiennej - zwłaszcza w dyskursie antysemickim - rasy.

Tymczasem Peruwianka z żydowskich cech swojej fizjonomii robi użytek. Czarne włosy i charakterystyczny kształt nosa, które były powodem powszechnej stygmatyzacji, teraz okazują się walorem. Tapada podkreśla, że semickie cechy pomagają jej, bo dzięki nim w ogóle może udawać Peruwiankę, nie tracąc z oczu powziętych celów. Mówi do Frankowskiego:

Peru to daleko - gdzieś za oceanem - czy ja wiem, ale to nie można sprawdzić. A ja czarna i mój żydowski nos do tego pasuje i tym ja dobre interesy robię. Tu nikt nie wie, kto ja jestem. Nie! Jedna policja, ale już z nimi nie zadzieram, bardzo solidnie żyję, to oni ze mną w zgodzie. Ja przed panem pierwszym prawdę powiedziałam ${ }^{36}$.

Jak zauważa Bożena Umińska ${ }^{37}$, kwestia kobieca na przełomie wieków przypomina nieco „kwestię żydowską”, skłaniając męską część społeczeństwa do zastanowienia się, czy nowy, wyemancypowany typ kobiety może „zasymilować się". Ta dwoistość dotyczy jednak przede wszystkim kobiet nie-Żydówek, dla których pozytywistyczne idee emancypacji miały być biletem do lepszej przyszłości. Żydówki muszą przejść drogę dwa razy dłuższą: najpierw opuścić kastę, a potem pokonać ograniczenia, które społeczeństwo przez wieki narzucało „słabej płci”. Są zatem jakby dwukrotnie stygmatyzowane: przez rasę i przynależność religijno-kulturową oraz przez płeć. Specyfika żydowskiego patriarchatu czyni to zadanie dodatkowo trudnym.

Peruwiance udaje się te bariery społeczne i psychiczne pokonać. Nie tylko wyrywa się z żydowskiego sztetla do wielkiego świata, ale także zdobywa w nim określoną pozycję materialną. Przekonując Frankowskiego do współpracy, mówi, że już dość się napracowała dla innych, teraz chce otworzyć własny salon. Cena, którą za to płaci, to m.in. wyrzeczenie się tożsamości, ale uzyskuje w zamian możliwość życia na własnych warunkach. Zapolska, podobnie jak Peruwianka, była świadoma ograniczeń żydowskiego patriarchatu, w którym kobiety stały znacznie niżej w hierarchii

${ }^{35}$ Zob. Sander Gilman, The Jew's Body, New York 1991, s. 38.

${ }^{36}$ Niedrukowane dramaty..., s. 107-108.

${ }^{37}$ Zob. Bożena Umińska, Postać z cieniem. Portrety Żydówek $w$ polskiej literaturze, Warszawa 2001, s. 37. 
społecznej niż mężczyźni. Kwestia, w której Tapada mówi, że chociaż jest kobietą i Żydówką, nie wyobraża sobie powrotu do Drohobycza, świadczy o tym, jak bardzo świadoma jest swojego położenia, jak doskonale zna swoje miejsce w szeregu i świetnie zdaje sobie sprawę z możliwości stojących przed nią w jej naturalnym środowisku społeczności żydowskiej.

\section{Figura chciwej Żydówki}

Odnoszę wrażenie, że Zapolska wykazuje się zrozumieniem dla Peruwianki, że darzy ją sympatią. Mimo to nie udało się jej uciec od nadania tej postaci antysemickiego retuszu. Do głosu dochodzi tu jeden z najbardziej elektryzujących fantazmatów związanych z Żydami, czyli pieniądze. Są one tematem rozmowy Peruwianki i Frankowskiego. Kobieta, próbując przekonać utracjusza do wejścia z nią w spółkę, zaznacza, że nie dość, iż robienie interesów ma we krwi, to jeszcze doskonale zna się na ludziach i wie, jaką wartość sobą reprezentują. Przy tym słowo „wartość” jest tutaj użyte w znaczeniu dosłownym, materialnym. „Po naszemu - ja z handlowej rodziny. Ja pana otaksowała, jak w lombardzie. Wiem, co pan jest wart"38.

Jak pisze Zygmunt Bauman, wiązanie judaizmu i pieniędzy jest bardzo głęboko zakorzenione w kulturze chrześcijańskiej Europy ${ }^{39}$. Rodzące się na przełomie wieków ogromne fortuny żydowskich rodzin burżuazyjnych podsycały zainteresowanie i budziły zazdrość. Stereotyp łączący Żydów z pieniędzmi jest niezwykle silnie obecny w zbiorowej świadomości również do czasów obecnych. W znaczący sposób przyczyniają się do tego antysemickie czasopisma, w tym tygodnik Jana Jeleńskiego „Rola”, propagujące wizerunki żydowskiego bankiera, lichwiarza, sprzedawcy, którego jedynym i najważniejszym celem jest zdobycie i pomnażanie pieniędzy ${ }^{40}$. Zarówno literatura wysoka, jak i ta przeznaczona dla mniej wyrobionego czytelnika pełna jest bohaterów żydowskich, których losy kręcą się wokół mamony i są przez nią determinowane ${ }^{41}$. Temu stereotypowemu myśleniu ulega też Zapolska, która konstruując postać Peruwianki, nie tylko nie ucieka od figury chciwego Żyda, lecz wręcz ją powiela, uwypuklając takie cechy

${ }^{38}$ Niedrukowane dramaty..., s. 109.

${ }^{39}$ Bauman, Nowoczesność i Zagłada..., s. 79.

40 Zob. Małgorzata Domagalska, Zatrute ziarno. Proza antysemicka na łamach „Roli” (1883-1912), Warszawa 2015, s. 210.

${ }^{41}$ Rolę literatury w kształtowaniu świadomości społecznej, wykorzystywanie utartych wzorców myślowych i powstawanie stereotypowych wyobrażeń opisuje Zofia Mitosek - zob. Zofia Mitosek, Literatura i stereotypy, Wrocław 1974. 
Tapady, jak: interesowność, merkantylne podejście do relacji międzyludzkich, stosowanie nieczystej gry w interesach. Choć z drugiej strony Zapolska podkreśla i zdaje się doceniać przymioty Żydówki, dzięki którym jest ona nie tylko samowystarczalna, ale także może samodzielnie decydować o sobie. Peruwianka jest tutaj kwintesencją kobiecej przebiegłości, sprytu, determinacji, bez których kobiety, a zwłaszcza Żydówki, nie miałyby szansy na wyjście z kasty i życie na własnych zasadach. Tapada przejmuje męskie sposoby postępowania, odrzucając te, które powszechnie uważa się za kobiece, ponieważ tylko w ten sposób można osiągnąć sukces. Używa języka, który współcześnie określilibyśmy jako biznesowy, tradycyjnie przypisywany mężczyznom. Propozycje Frankowskiemu składa wprost i bez ogródek:

A teraz będziemy gadać o interesie. Krótko - raz, dwa. Pan jest duży, rosły, dobrze się pan rusza, umie pan gadać i ma pan dobre nazwisko. No! Nie takie prima sorta, ale niezłe. Potem - pan jest bez sumienia i pan się z niczym nie liczy. To już bardzo wiele. Oto - ja chcę założyć dom gry w Paryżu i potrzebuję do tego reprezentanta. Kogoś, kto by umiał honory robić - i prowadzić grę, i miał znajomości porządne, i takich, co przyjeżdżają do nas do Paryża przyprowadził... [...] Ja będę hrabina albo księżna - co sobie tam po drodze wymyślimy. Pan będzie albo mój brat, albo mój mąż, albo mój przyjaciel, co pan zechce. [...] Ja mam dosyć pracować na drugich, ja wolę na siebie. Do tego mi trzeba mężczyzny. Pan się na to nadaje jak rękawiczka....22.

Kobieta, na dodatek Żydówka, w sposób niepozostawiający żadnych wątpliwości mówi otwarcie nie tylko o planach zawodowych, ale także łamie wszelkie obowiązujące w patriarchalnej kulturze konwenanse. Nieważne, jaką rolę ma pełnić Frankowski. To, czego Peruwianka potrzebuje, to jego płeć, w znaczeniu gender ${ }^{43}$, bo tylko mężczyzna w tym zmaskulinizowanym świecie może prowadzić biznes i odnieść sukces. Frankowski ma się stać w rękach Peruwianki czymś w rodzaju pionka za sowitą opłatę sankcjonującego społecznie interesy, które ona - sterując z tylnej kanapy planuje prowadzić. Oprócz wymienianych już wcześniej cech mężczyzny, takich jak bezwzględność czy brak sumienia dla Peruwianki, dodatkową zaletą Frankowskiego w oczach kokoty jest jego uroda. Dochodzi tu do

${ }^{42}$ Niedrukowane dramaty..., s. 109-110.

43 „Gender” rozumiem tutaj jako kulturowo-społeczną konstrukcję płci. Przyjmuję za Maggie Humm, że zarówno męskość, jak i kobiecość to konstrukty społeczne funkcjonujące w kulturze. Oznacza to, że obowiązują pewne wzory męskości i kobiecości, którym następnie przypisuje się określone role. Zob. Maggie Humm, Słownik teorii feminizmu, tłum. Bożena Umińska, Jarosław Mikos, Warszawa 1993. 
odwrócenia ról. Piękne rysy twarzy, ułatwiające załatwienie lub uzyskanie czegoś, były domeną kobiet, a pieniądze i bogactwo należały do instrumentarium, dzięki któremu pozycja mężczyzny była niezachwiana. Tutaj to kobieta dysponuje majątkiem i bierze mężczyznę, który jej się podoba. Co ciekawe, Peruwianka daje Frankowskiemu wybór: może nie podjąć z nią współpracy, ale musi się zobowiązać, że zachowa dla siebie informację, kim ona jest naprawdę.

\section{Stygmatyzacja przy użyciu języka}

Inny jeszcze aspekt stygmatyzacji Żydówki dokonywanej przez Zapolską wiąże się z językiem. Przejawia się on w stylizowaniu mowy, którą posługuje się Peruwianka, na żydowską odmianę polszczyzny. To, co mówi Żydówka, wyróżnia się na tle wypowiedzi Frankowskiego poprzez sposób konstruowania zdań, odmienną normę gramatyczną, wymowę. Ujawnia się zatem na wielu płaszczyznach wypowiedzi - od fonologicznej po semantyczną. Lektura dramatu Zapolskiej nie pozostawia złudzeń, że Peruwianka w czasie rozmowy z Frankowskim „żydłaczy”, czyli moduluje głos i akcentuje wyrazy w taki sposób, jaki jest charakterystyczny dla tej mniejszości narodowej ${ }^{44}$. Najczęściej stosowanym przez pisarkę zabiegiem, będącym jednocześnie przejawem przenikania się polszczyzny i języka jidysz, jest stosowanie takiej konstrukcji, która polega na używaniu zaimka osobowego jako części formy koniugacyjnej. Peruwianka mówi: „Ja panu wierzę, bo się pan będzie bał, żebym ja gęby nie rozpuściła z tą bransoletką”; „Jakby się mój projekt panu nie nadał, to niech pan nikomu nie mówi, że ja jestem z naszych, i z Galicji. Ja będę znów Peruwianką - i znów nie będę nic rozumieć. Zresztą i tak niedługo, bo ja wracam do Paryża"45. W rozmowie z Marią, która jako druga dowiaduje się, kim naprawdę jest Peruwianka, ta się odzywa: „Będziemy mówiły po polsku, bo ja jestem Polka - to jest, ja jestem Żydówka, ale to obojętne...”; „Pani mnie nie prosi siedzieć, ale ja usiądę, bo hotel to nie dom, a potem interes, to się załatwia spokojnie i powoli" ${ }^{46}$. Ten przerost formalno-znaczeniowy w postaci nadmiarowego używania zaimka ,ja”, stosowanie nieprawidłowych form przypadków (mianownika zamiast narzędnika), niegramatycznych form czasowników, naruszanie stałej łączliwości wyrazów potęgują odmienność postaci

\footnotetext{
${ }_{44}$ Maria Brzezina, Polszczyzna Żydów, Warszawa 1996, s. 562.

${ }^{45}$ Niedrukowane dramaty..., s. 108-109.

46 Tamże, s. 134-135.
} 
Peruwianki, a także pokazują, jak prostą i niewykształconą, choć brylującą na salonach Paryża i Nicei, jest osobą. Język określa status społeczny kobiety, nie tylko jej przynależność etniczną. Jak podkreśla Michał Głowiński, „Literatura nie tyle czerpie środki z mowy danej grupy społecznej, na nich się opiera i nimi operuje, ile je przedstawia" ${ }^{47}$. W tym znaczeniu odwzorowywanie języka, ujawnianie różnych jego uwikłań, ograniczeń czy mechanizmów, które nim rządzą, niezależnie od tego, w jaki sposób się realizują, stanowi jego krytykę.

Jak łatwo się domyślić, sygnały obcości językowej musiały wyraźnie wybrzmiewać, gdy Nerwowa awanturę na scenie mogła podziwiać krakowska publiczność. Boya-Żeleńskiego nie bez powodu zachwyciła kwestia wypowiadana przez Halinę Górską, która na deskach Teatru im. Słowackiego grała Peruwiankę i z żydowskim akcentem oraz używając charakterystycznego zmiękczenia na końcu zdania, mówiła do Frankowskiego: „Oddaj mi pan moje branzoletkie".

\section{Między oryginalnością a stereotypem}

Peruwianka jest kolejną kobietą Żydówką w twórczości Zapolskiej. Co ważne, pisarka wychodzi poza schemat najbardziej popularnej postaci żydowskiej w literaturze drugiej połowy XIX i pierwszych dziesięcioleci XX w., czyli handlarki, choć i ta pojawia się w jej tekstach, ale jako postać drugo- czy trzecioplanowa. A nawet jeśli Zapolska sięga po bohaterki literackie, które są mało oryginalne, bo powszechnie obecne w twórczości innych pisarzy, nadaje im nowy rys. Wystarczy spojrzeć na Małkę Szwarcenkopf $^{48}$, biedną żydowską nauczycielkę, ofiarę nieudanej asymilacji. Małka nie chce żyć w tradycyjnej rodzinie żydowskiej, lecz mimo zdobytego wykształcenia, bycia kobietą oświeconą i z ambicjami nie może znaleźć sobie miejsca wśród Polaków, w społeczeństwie, do którego aspirowała. Chociaż dramat Matka Szwarcenkopf - pierwszy z dwóch tzw. dramatów żydowskich Zapolskiej, wydany w 1897 r. - nie był ani przez krytyków, ani przez nią samą zbytnio ceniony, to recenzenci dostrzegli w nim wiele walorów, przede wszystkim skupiając się na docenieniu Zapolskiej za wierne oddanie realiów panujących w środowisku żydowskim. Jak podkreśla Danuta Knysz-Tomaszewska, Zapolska sama - jako kobieta

${ }^{47}$ Michał Głowiński, Czy literatura może być wzorem mowy, [w:] Postugiwanie się znaka$m i$, red. Stefan Żółkiewski, Maryla Hopfinger, Wrocław 1991, s. 29.

48 Gabriela Zapolska, Małka Szwarcenkopf, [w:] taż, Dzieła wybrane, t. 13, Kraków 1958. 
i artystka - wielokrotnie walczyła z ograniczeniami narzucanymi jej przez patriarchalną kulturę, czemu raz po raz dawała wyraz zarówno w swojej twórczości prozatorskiej, jak i dramatycznej. „Trudna walka o skąpe zarobki autorskie i o przetrwanie w świecie teatru i literatury uczyniły ją szczególnie wrażliwą na nędzę ludzką, przemoc psychiczną i obojętność społeczeństwa na nieszczęścia kobiet samotnych, szczególnie tych z gminu" ${ }^{49}$. Widać to doskonale na przykładzie wspomnianej wcześniej Irmy, głównej postaci szkicu powieściowego pt. Antysemitnik. To pierwszy w historii literatury polskiej utwór, gdzie niechęć do Żydów wkracza w relację intymną, damsko-męską, miłosną, doprowadzając ją do ruiny. Jeszcze innym typem kobiety Żydówki stworzonej przez Zapolską jest Resia, niefrasobliwa bohaterka króciutkiego opowiadania pt. Kundel, wchodzącego w skład cyklu Menażeria ludzka ${ }^{50}$. Resia jest niezwykła nie tylko dlatego, że jednocześnie jest Żydówką i antysemitką, ale przede wszystkim dlatego, że jest bodaj pierwszą w literaturze polskiej postacią, której żydowskie pochodzenie zostaje zneutralizowane, pozbawione pejoratywnego nacechowania i obcości dzięki wprowadzeniu efektu komicznego. Przeciwieństwem Resi jest Trejne, zdecydowanie negatywna bohaterka powieści Szmat życia ${ }^{51}$. Młoda, piękna Żydówka jest symbolem niepohamowanego erotyzmu i zwierzęcości wynikających z tajemniczych związków z naturą, pozwalających na panowanie nad wszystkim tym, co do niej należy, także nad męską seksualnością. Bezkarnie i świadomie rozkochuje w sobie wszystkich mężczyzn, którzy stają się od niej w pewnym sensie uzależnieni, włada siłami natury, wychodzi bez szwanku z płomieni. Trudno nie zauważyć w tej demonicznej postaci cech przypisywanych czarownicom. Zatem z jednej strony czytelnik lub widz ma do czynienia ze światową i elegancką prostytutką, robiącą we Francji karierę finansową, z drugiej zaś z półdziką, rozbudzającą seksualnie każdego mężczyznę siostrą Lilith.

Tym, co bez wątpienia wyróżnia twórczość Zapolskiej i sposób kreowania postaci kobiecych, jest sięganie po zestawy cech pochodzące od zupełnie różnych typów charakterologicznych. Żydówki Zapolskiej wyróżnia złożoność psychologiczna i nietuzinkowość. Wykreowane przez nią bohaterki literackie często są oryginalnymi postaciami, których pierwowzorów próżno szukać w literaturze wcześniejszych epok. Tak też jest

${ }^{49}$ Knysz-Tomaszewska, Gabriela Zapolska..., s. 20-21.

${ }^{50}$ Gabriela Zapolska, Kundel, [w:] taż, Menażeria ludzka, tekst opracowany na podstawie: taż, Menażeria ludzka, Poznań 1994, oraz taż, Nowele, Kraków 1958, https://wolnelektury.pl/katalog/lektura/menazeria-ludzka-kundel.html [dostęp: 27 sierpnia 2021].

${ }^{51}$ Gabriela Zapolska, Szmat życia, Warszawa 1912, [ebook, format: mobi]. 
z Peruwianką. Zabiegiem dość powszechnym w literaturze tego okresu jest orientalizacja żydowskiego ciała. I Zapolska stosuje ten chwyt nie bez powodu; jak zauważa Edward Said, Orient jest ,jednym z najmocniejszych, najgłębiej utrwalonych europejskich obrazów Obcego"52. Ale Zapolska idzie dalej - orientalne cechy swojej bohaterki niejako przykrywa egzotycznym kamuflażem peruwiańskiej księżniczki. Tapada nie przypomina też prostytutek znanych w tradycji literackiej. Nie zależy jej na rozkochiwaniu w sobie swoich kochanków, nie czyha też na ich pieniądze, jak to było w przypadku bohaterek Balzaka czy Zoli. Raczej przywodzi na myśl powszechnie występujący w literaturze zachodniej, a zupełnie obcy w rodzimej53 typ Żydówki salonowej - pięknej, bywałej w świecie, często wykształconej. Peruwianka nie pragnie bliskiej relacji z Frankowskim - potrzebuje go, bo jest mężczyzną, który może reprezentować ją w interesach.

Zapolskiej jednak nie udaje się uchronić przed stereotypami. Wiążą się one przede wszystkim z wizerunkiem prostytutki wyzutej z uczuć wyższych oraz łączenia Żydów z pieniędzmi, chciwością i handlem jako profesją, która mają we krwi, co stało się jednym z najistotniejszych toposów antysemickiej propagandy. Kolejny fantazmat dotyczy odmienności fizjonomii żydowskiej (w tym języka), której proces medykalizacji rozwinął się na niespotykaną skalę na przełomie wieków wraz z rozwojem antropologii i medycyny. Trudno jednak oprzeć się wrażeniu, że stereotypy te zostały osadzone w praktyce społecznej, a rozpoznania Zapolskiej okazały się trafne. Były one efektem jej niezwykłego zmysłu obserwacyjnego, wyczulenia na kwestie kobiece, wrażliwości na to, co niejednoznaczne i zakryte.

52 Cyt. za: Maria Janion, Bohater, spisek, śmierć. Wykłady żydowskie, Warszawa 2009, s. 150 .

53 Jak podkreśla Bożena Umińska, w polskiej twórczości literackiej brakuje postaci salonowej Żydówki, za to często występuje Żydówka „orientalna”: „Ten typ pięknej, bogato i wytwornie ubranej kobiety, o ciemnym typie urody kojarzył się ze Wschodem, nie z judejskim, raczej ogólnie ze wschodnim przepychem, lenistwem i bogactwem". Umińska, Postać z cieniem..., s. 130 . 


\section{Bibliografia}

\section{1. Źródła opublikowane}

Boy-Żeleński Tadeusz, Pisma, t. 20, red. Henryk Markiewicz, oprac. i przedmowa Jan Kott, Warszawa 1963.

Niedrukowane dramaty Gabrieli Zapolskiej, t. 1: „Nerwowa awantura” oraz „Pariasy”, red. Jan Jakóbczyk, Katowice 2012, [e-book, format: mobi].

Pappenheim Bertha, Zur Lage der jüdischen Bevölkerung in Galizien: Reise-Eindrücke und Vorschläge zur Besserung der Verhältnisse, Frankfurt am Main 1904.

Pollack Martin, Cesarz Ameryki. Wielka ucieczka z Galicji, tłum. Karolina Niedenthal, Wołowiec 2012.

Posner Stanisław, Nad otchtania (w sprawie handlu żywym towarem), cz. 1, Warszawa 1903, https://bc.radom.pl/dlibra/show-content/publication/edition/ 25331? id=25331 [dostęp: 27 sierpnia 2021].

Zapolska Gabriela, Antysemitnik, Kraków 1921.

Zapolska Gabriela, Kundel, [w:] taż, Menażeria ludzka, tekst opracowany na podstawie: taż, Menażeria ludzka, Poznań 1994, oraz taż, Nowele, Kraków 1958, https://wolnelektury.pl/katalog/lektura/menazeria-ludzka-kundel.html [dostęp: 27 sierpnia 2021].

Zapolska Gabriela, Listy, t. 2, oprac. Stefania Linowska, Warszawa 1970.

Zapolska Gabriela, Małka Szwarcenkopf, [w:] taż, Dzieła wybrane, t. 13, Kraków 1958.

Zapolska Gabriela, Szmat życia, Warszawa 1912, [ebook, format: mobi].

\section{Opracowania}

Bauman Zygmunt, Nowoczesność i Zagłada, Kraków 2009.

Brzezina Maria, Polszczyzna Żydów, Warszawa 1996.

Czachowska Jadwiga, Gabriela Zapolska. Monografia bio-bibliograficzna, Kraków 1966.

Domagalska Małgorzata, Zatrute ziarno. Proza antysemicka na łamach „Roli” (1883-1912), Warszawa 2015.

Gilman Sander, The Jew's Body, New York 1991.

Gilmore David D., Mizoginia, czyli męska choroba, tłum. Janusz Margański, Kraków 2003.

Głowiński Michał, Czy literatura może być wzorem mowy, [w:] Postugiwanie się znakami, red. Stefan Żółkiewski, Maryla Hopfinger, Wrocław 1991.

Gutowski Wojciech, Nagie dusze i maski: o młodopolskich mitach miłości, Kraków 1992.

Humm Maggie, Słownik teorii feminizmu, tłum. Bożena Umińska, Jarosław Mikos, Warszawa 1993.

Janion Maria, Bohater, spisek, śmierć. Wykłady żydowskie, Warszawa 2009.

Knysz-Tomaszewska Danuta, Gabriela Zapolska, pisarka zbuntowana (1857-1921). Biografia niepokorna, [w:] Gabriela Zapolska. Zbuntowany talent, red. Monika Chudzikowska, Warszawa 2011. 
Matuszek Gabriela, Kultura contra natura? O mizoginizmie minionego fin de siècle’u, [w:] W kręgu Młodej Polski. Prace ofiarowane Marii Podrazie-Kwiatkowskiej, red. Marian Stala, Franciszek Ziejka, Kraków 2001.

Mitosek Zofia, Literatura i stereotypy, Wrocław 1974.

Nowakowska Paulina, Tapadas limeñas, patrzace na świat jednym okiem, tajemnicze kobiety Wicekrólestwa Peru, „Palimpsest” (marzec 2012), nr 2, https://docplayer. pl/2880426-Tapadas-limenas-patrzace-na-swiat-jednym-okiem-tajemnicze-kobiety-wicekrolestwa-peru.html [dostęp: 27 sierpnia 2021].

Podraza-Kwiatkowska Maria, Salome i Androgyne. Mizoginizm a emancypacja, [w:] taż, Symbolizm i symbolika w poezji Młodej Polski. Teoria i praktyka, Kraków 1975.

Showalter Elaine, Przedstawiając Ofelię: kobiety, szaleństwo i zadania krytyki feministycznej, [w:] Ciało i tekst. Feminizm w literaturoznawstwie - antologia szkiców, red. Anna Nasiłowska, Warszawa 2001.

Umińska Bożena, Postać z cieniem. Portrety Żydówek w polskiej literaturze, Warszawa 2001.

Weininger Otto, Pteć i charakter, tłum. Ostap Ortwin, Warszawa 1994.

Wojnicka Katarzyna, Otto Weininger: mizogin i profeminista?, „Autobiografia. Literatura. Kultura. Media” (2016), nr 1.

Wolff Larry, Idea Galicji. Historia i fantazja w kulturze politycznej Habsburgów, tłum. Tomasz Bieroń, Kraków 2020.

Katarzyna Trębacka

Uniwersytet Warszawski

kj.trebacka@uw.edu.pl 